\title{
PROPERTY RIGHTS, HOUSING, AND THE AMERICAN CONSTITUTION: THE SOCIAL BENEFITS OF PROPERTY RIGHTS PROTECTION, GOVERNMENT INTERVENTIONS, AND THE EUROPEAN COURT ON HUMAN RIGHTS' HUTTEN- CZAPSKA DECISION ${ }^{*}$
}

\author{
Edward H. Ziegler ${ }^{* *}$ and Jan G. Laitos ${ }^{* * *}$
}

\begin{abstract}
Nations around the world utilize government interventions to promote the availability and affordability of housing. This Article focuses on various types of government regulatory interventions, such as rent controls, building dedications and exactions, and density and growth controls on housing. These interventions are common in the United States and in other countries and may contribute to inefficient resource allocation and poor housing outcomes. This Article examines whether these types of government interventions may require, in particular cases in the United States, judicially required compensatory damages for affected property owners. The social costs of these forms of government intervention are examined from the perspective of the benefits accruing from a regime of property rights protection. This Article further explains that there is some existing precedent under international human rights norms, as illustrated by the Hutten-Czapska v. Poland decision, for the standards used in the United States for protecting the property rights of owners and developers of housing from excessive and unwise government regulation.
\end{abstract}

\section{INTRODUCTION}

The U.S. Constitution provides protection for private property owners when the government intervenes through official regulations restricting an owner's rights in land or housing. ${ }^{2}$ When the government acts through regulatory intervention that restricts the private use of land and housing, the

* C2010 Edward Ziegler and Jan Laitos

** Edward H. Ziegler is Robert B. Yegge Memorial Research Chair and Professor of Law at the University of Denver - Sturm College of Law. The author wishes to thank Ms. Katy Michaelis for her assistance in the preparation and editing of this article.

*** Jan G. Laitos is John A. Carver Jr. Professor of Law at the University of Denver Sturm College of Law. Professor Laitos wishes to acknowledge the valuable assistance provided by Elizabeth McDermott in the preparation and development of this article.

1. Hutten-Czapska v. Poland, 45 Eur. Ct. H.R. 4 (2007).

2. See 1 Edward H. Ziegler, JR., Rathkopf's The law of Zoning and PlanNing $\S$ 6:2-3 (4th ed. 2010) [hereinafter ZIEGLER, RATHKOPF's]. 
property rights of affected owners are protected under the Fourteenth Amendment and the Takings Clause of the Fifth Amendment of the U.S. Constitution. ${ }^{3}$ These provisions apply regardless of the personal status or income of the affected private owner. ${ }^{4}$

Government intervention by police power regulation of land and housing in the United States is constrained by judicial interpretation of the constitutional protection afforded private owners of property. The Fifth Amendment of the U.S. Constitution provides that "[n]o person shall be . . . deprived of life, liberty or property without due process of law; nor shall private property be taken for public use, without just compensation." The next section of this Article discusses the legal protection afforded private housing and landowners by the U.S. Constitution's Takings Clause and the court decisions interpreting this provision.

To a significant degree, the constitutional protection of property rights for owners of real property in the United States is reflected in the European Court on Human Rights' Hutten-Czapska decision, which involved rent controls imposed on apartment housing in Poland. ${ }^{6}$ The European Court ruled that rent controls violated the right to property in the European Convention on Human Rights. Over time, rent controls denied a housing owner any economically viable use of his property, which amounted to a disproportionate and impermissible benefit extraction of the owner's interest in the property. ${ }^{7}$ The rationale of the Court's decision closely parallels the U.S. Supreme Court's analysis of the protection of private property under the U.S. Constitution. ${ }^{8}$

The constitutional protection of private property rights in the United States is thought to promote economic prosperity and efficiency, as well as basic fairness and individual liberty. ${ }^{9}$ In this sense, private property rights are institutionally considered important human and civil rights that operate to protect a disfavored minority from favoritism and unfairness caused by majority legislative action. ${ }^{10}$ In the United States, while a right to housing is not codified, there is no shortage of quality housing space available at

3. Id.

4. Id. $\S 6: 2$.

5. The Fifth Amendment is held applicable to state and local regulation by its incorporation into the Due Process Clause of the Fourteenth Amendment. State constitutions also contain similar due process and takings clauses. Some state constitutions grant greater protections than the guarantees provided under the Fifth and Fourteenth Amendments. Id.

6. Hutten-Czapska v. Poland, 45 Eur. Ct. H.R. 4 (2007).

7. See id.

8. See infra notes $65-67$ and accompanying text.

9. See generally JaN G. LAITOS, LaW of Property Rights Protection: Limitations ON GOVERNMENTAL POWER (2005).

10. Edward H. Ziegler, Fundamental Fairness and Regulatory Takings: Judicial Standards of Fairness Shaping the Limits of Categorical and Partial Taking Claims, 1996 INST. ON PLAN. ZONING \& EMINENT DOMAIN 11-1 [hereinafter Fundamental Faimess]. 
market prices. Also, on a comparative and absolute basis, the United States provides substantial public and private financial support for housing the very poor and homeless. ${ }^{11}$ The U.S. housing market is highly influential across the globe, ${ }^{12}$ likely due, at least in part, to the constitutional protection of the property rights of private owners and renters of housing.

\section{TAKING PRIVATE PROPERTY AND THE RIGHT TO COMPENSATION}

The U.S. Constitution's Takings Clause requires that an owner be paid just compensation when the government takes private property for a public use. ${ }^{13}$ Compensation must be paid to an owner when the government directly takes title to private property to establish a new public use, like a public park. ${ }^{14}$ However, courts have also ruled that a taking occurs, and compensation must be paid, when the government interferes in certain ways with an owner's possessory interests, while acting in an enterprise capacity or by a police power regulation of private property rights. ${ }^{15}$ These situations are known as cases of inverse condemnation, in which there is no direct taking of title. The government often contests in court whether compensation is required. ${ }^{16}$ These cases are controlled by the general jurisprudential taking principle that police power regulation of

11. See, e.g., NAT'L AllianCE to END Homelessness, ANNUAL RePORT 2008 (2008), available at $\mathrm{http}: / / \mathrm{www}$.endhomelessness.org/content/article/detail/2547; U.S. INTERAGENCY COUNCIL ON HOMELESSNESS, http://www.ich.gov/ (last visited Nov. 26, 2010).

12. World Housing Market, ECONOMY WATCH, http://www.economywatch.com/market/ housing-market/world.html (last visited Jan. 31, 2011).

13. Edward H. Ziegler, Partial Taking Claims, Ownership Rights in Land and Urban Planning Practice: The Emerging Dichotomy Between Uncompensated Regulation and Compensable Benefit Extraction under the Fifth Amendment Takings Clause, 22 J. LAND ResourCES \& ENVTL. L. 1 (2002) [hereinafter Ziegler, Partial Taking].

14. See Allison Duham, A Legal and Economic Basis for City Planning, 58 Colum. L. Rev. 650, 666-67 (1958); see also ZIEGLER, RATHKOPF's, supra note 2,§ 6:34; Ziegler, Partial Taking, supra note 13, at 9.

15. See ZIEGLER, RATHKOPF's, supra note $2, \S 6: 3$; see generally LAITOS, supra note 9; Ziegler, Partial Taking, supra note 13.

16. See, e.g., United States v. Causby, 328 U.S. 256 (1946) (direct overflights destroyed present use of land as a chicken farm); United States v. Cress, 243 U.S. 316 (1917) (repeated flooding of land caused by water project); see also Moden v. United States, 60 Fed. Cl. 275, 282 (Fed. Cl. 2004) (test for distinguishing a taking from a tort in inverse condemnation cases involves a two-part inquiry: (1) "a property loss compensable as a taking only results when the government intends to invade a protected property interest $o r$ the asserted invasion is the "direct, natural, or probable result of an authorized activity and not the incidental or consequential injury by the action," and (2) "“the nature and magnitude of the government action must be considered. Even where the effects of the government action are predictable, to constitute a taking, an invasion must appropriate a benefit to the government at the expense of the property owner, or at least preempt the owner[']s right to enjoy his property for an extended period of time, rather than merely inflict an injury that reduces its value"”) (quoting Ridge Line, Inc. v. United States, 346 F.3d 1346, 1355-56 (Fed.Cir.2003), aff'd, 404 F.3d 1335 (Fed. Cir. 2005)). 
private property may not be used simply as a mechanism for extracting public benefits from private landowners that, in all fairness and justice, should be paid for by the public as a whole. ${ }^{17}$

Courts have recognized that land value consists not only in title ownership and possession, but also in the rights of an owner to use, enjoy and develop the land. ${ }^{18}$ Since all property is subject to the exercise of government regulation in protection of the public welfare, government regulation of land will not be held a taking simply because it partially reduces or destroys the use or development value of the land. ${ }^{19}$ Justice Holmes argued that "government hardly could go on if to some extent values incident to property could not be diminished without paying for every change in the general law." ${ }^{20}$ However, Holmes also recognized, in view of the policies underlying the due process and takings provisions in the U.S. constitutional system, that "if regulation goes too far it will be

17. See Armstrong v. United States, 364 U.S. 40 (1960). Recent U.S. Supreme Court taking decisions continue to embrace this ultimate taking standard. See Agins v. City of Tiburon, 447 U.S. 255, 260 (1980) ("The determination that governmental action constitutes a taking is, in essence, a determination that the public at large, rather than a single owner, must bear the burden of an exercise of state power in the public interest."); see also First English Evangelical Lutheran Church v. Los Angeles Cnty., 482 U.S. 304, 318-19 (1987) ("It is axiomatic that the Fifth Amendment's just compensation provision is 'designed to bar Government from forcing some people alone to bear public burdens which, in all fairness and justice, should be borne by the public as a whole"') (quoting Armstrong, 364 U.S. at 49)). The following cases contain the same quote from Armstrong: Dolan v. City of Tigard, 512 U.S. 374, 384 (1994); Concrete Pipe \& Prods. of Cal., Inc. v. Constr. Laborers Pension Trust for S. Cal., 508 U.S. 602, 646-47 (1993); Nollan v. Cal. Coastal Comm'n, 483 U.S. 825,835 n. 4 (1987); and Penn Cent. Transp. Co. v. City of New York, 438 U.S. 104, 123 (1978).

18. The U.S. Supreme Court and all state courts recognize that, short of taking title to property, a police power restriction on land use may "go too far" and constitute an unconstitutional taking of property for public use, due to government's failure to pay compensation for the use or development interests thereby destroyed. As Justice Brennan stated in San Diego Gas \& Electric Co. v. City of San Diego, "Police power regulations such as zoning ordinances and other land-use restrictions can destroy the use and enjoyment of property in order to promote the public good just as effectively as formal condemnation or physical invasion of property. From the property owner's point of view, it may matter little whether his land is condemned or flooded, or whether it is restricted by regulation to use in its natural state, if the effect in both cases is to deprive him of all beneficial use of it. From the government's point of view, the benefits flowing to the public from preservation of open space through regulation may be equally great as creating a wildlife refuge through formal condemnation or increasing electricity production through a dam project that floods private property." 450 U.S. 621, 652 (1981). See also Phillips v. Wash. Legal Found., 524 U.S. 156 (1998) (for purposes of taking analysis, property consists of a group of rights including the owner's right to possess, use, and dispose of it); Nollan, 483 U.S. at 833, n.2 ("[T] he right to build on one's own property - even though its exercise can be subjected to legitimate permitting requirements - cannot remotely be described as a "governmental benefit."').

19. See ZIEGLER, RATHKOPF's, supra note 2, § 6:3; see generally LAITOS, supra note 9; Fundamental Fairness, supra note 10, at 11-19.

20. Pa. Coal Co. v. Mahon, 260 U.S. 393, 413 (1922). 
recognized as a taking." 21 The police power "must have its limits" and "when it reaches a certain magnitude, in most if not all cases, there must be an exercise of eminent domain and compensation to sustain the act." ${ }^{22}$

The Takings Clause in the U.S. Constitution plays a significant role in shaping the limits and forms of government regulation that are sought for housing or new housing development. ${ }^{23}$ All three types of the constitutional taking claims discussed below - physical invasion analysis, economically viable use analysis, and partial benefit-extraction analysis significantly restrict the methods of government intervention that may address perceived social problems related to housing in the United States. ${ }^{24}$

\section{A. Physical Invasion Takings Analysis}

A regulation adopted by a governing authority that allows someone to enter another person's property will likely be considered a physical invasion taking of the private right to exclusive possession for which

21. Id. at 415.

22. Id. at 413 .

23. The Fifth Amendment Takings Clause presupposes the fundamental unfairness of the uncompensated taking of private property for public use or benefit. In the regulatory takings context, analysis of fundamental faimess in allocation of the burdens imposed, in view of the policy of horizontal equity (the approximation of equal sharing of costs or of sharing according to capacity to pay that exists when property is taken by the expenditure of public funds) underlying the Takings Clause, secures and implements its original meaning and purpose. Thus, the Supreme Court noted "the oft-cited maxim that "while property may be regulated to a certain extent, if regulation goes too far it will be recognized as a taking."” Lucas v. S.C. Coastal Council, 505 U.S. 1003, 1014-15 (1992) (quoting Pa. Coal Co., 260 U.S. at 415).

24. See Richard Epstein, Takings: Private Property and the Power of Eminent DOMaIn 138 (1985); Frank I. Michelman, Possession vs. Distribution in the Constitutional Idea of Property, 72 IowA L. REV. 1319, 1329 (1987); Antonin Scalia, Economic Affairs as Human Affairs, 4 CaTo J. 703, 703-04 (1985); see also Jan Laitos, The Strange Career of Private Property and the Police Power, 40A RockY MTN. MIN. L. INST. 2, 2-35 (1995) ("This protection is occurring in three general ways. First, courts are beginning to strike laws whose primary defect is that they have unfairly affected private property interests. The main theories used by courts to defend property against police power exercises that are fundamentally unfair are (1) presumptions against retroactivity; (2) vested rights; and (3) equitable estoppel. Second, certain property-protective clauses in the Constitution are being activated by courts (particularly the United States Supreme Court and the United States Federal Circuit Court of Appeals) to resist government regulations of land and property. These clauses are (1) the Takings Clause; (2) the Contracts Clause; and (3) the Due Process Clause. Third, the United States Congress has proposed legislation that would require agencies to pay compensation to landowners whose property value has been diminished by police power exercises. In a perfect reflection of the nation's newly discovered interest in the role of private property, many of these bills are entitled 'The Private Property Owners Bill of Rights.'”). 
compensation must be paid. ${ }^{25}$ The U.S. Supreme Court has adopted a per $s e$ confiscation taking rule that applies when government interferes, through regulation, with an owner's possessory interest in excluding others from his property. ${ }^{26}$ Under this analysis, a taking occurs when regulation results in a permanent physical invasion of private property or an interference with an owner's right to exclude others from his property, which disturbs his reasonable investment-backed expectations. ${ }^{2 f}$ For example, in Loretto $v$. Teleprompter Manhattan CATV Corp, the Supreme Court held that a New York law requiring a landlord to permit installation of cable television on his property constituted a taking. ${ }^{28}$ Similarly, a taking would be found if the government was to require owners of private apartments to provide free housing for the poor or homeless. ${ }^{29}$ In such cases, the government would have to compensate the private owner for the fair market rental value for the possession of the apartments. However, extensive government regulation of all aspects of the landlord-tenant relationship is generally allowed within the constitutional parameters discussed below. ${ }^{30}$

\section{B. Economically Viable Use Analysis}

Zoning, urban planning, public design controls, and other forms of government intervention by regulation will not be held confiscatory simply because regulation prohibits the owner from making the most profitable use of the property or results in a substantial diminution in market value of the land. $^{31}$ Generally, a regulation will be held confiscatory only where it deprives an owner of every use to which the property is reasonably adapted. $^{32}$ Recently, the U.S. Supreme Court and most state courts have

25. See Keystone Bituminous Coal Ass'n v. DeBenedictis, 480 U.S. 470, 516 (1987); Loretto v. Teleprompter Manhattan CATV Corp., 458 U.S. 419, 430 (1982).

26. See Loretto, 485 U.S. at 426-435; see also Penn Central Transp. Co. v. City of New York, 438 U.S. 104, 124-25 (1978).

27. See Loretto, 485 U.S. at 426-435; see also Penn Central Transp. Co., 438 U.S. at 124-25 (1978).

28. Loretto, 485 U.S. at 438.

29. See Ziegler, Partial Taking, supra note 13, at 13-14.

30. See, e.g., Aspen-Tarpon Springs Ltd. P'ship v. Stuart, 635 So. $2 \mathrm{~d} 61$ (Fla. Dist. Ct. App. 1994) (statute requiring mobile park owners to either buy tenants' homes or pay relocation costs held a regulatory taking); Manocherian v. Lenox Hill Hosp., 643 N.E.2d 479 (N.Y. 1994) (holding statute that required owners to provide renewal leases to non-private hospitals based on primary residency status of hospital's employee-subtenant affected partial regulatory taking); Seawall Assocs. v. City of New York, 542 N.E.2d 1059 (N.Y. 1989) (ordinance preventing destruction or conversion of single-room occupancy buildings is facially invalid as a regulatory taking).

31. See ZIEGLER, RATHKOPF's, supra note 2 , § 6:11; see generally LAITOS, supra note 9.

32. ZIEGLER, RATHKOPF's, supra note $2, \S \S 6: 14,6: 22$. 
adopted the economically viable use test. ${ }^{33}$ Under this test, a regulation generally will not be held confiscatory unless it denies an owner all reasonably beneficial and economically viable use of the land considered as a whole. ${ }^{34}$ A regulation may be held confiscatory even if an owner is afforded a beneficial or economically viable use of the property under either of the alternative takings tests. ${ }^{35}$

Applying the economically viable use analysis, the purchase price paid by a present owner and the decline in market value as a result of regulation are unlikely to be determinative in whether a taking has occurred and compensation must be paid. ${ }^{36}$ However, the testimony of an appraiser or real estate expert regarding the market value of land developed for allowed uses may constitute an important part of a landowner's confiscation claim. ${ }^{37}$ Market value and demand for permitted land uses, taken together, may demonstrate that such potential uses are not reasonably beneficial and economically viable uses for the land in question, rendering the regulation confiscatory. ${ }^{38}$ For example, where a landowner's proof demonstrated that, upon completion of a residence on a lot, the market value of the house and lot would be less than the cost of constructing the residence, the regulation was confiscatory because the lot was held to be unsuitable and valueless for residential use. $^{39}$ Similarly, denial of a variance to operate a gasoline station in an area zoned for retail business was confiscatory based on a finding that the area was so undeveloped, residentially and otherwise, that

33. ZIEGLER, RATHKOPF'S, supra note $2, \S 6: 15$; see also, e.g., Fla. Rock Indus., Inc. v. United States, 18 F.3d 1560, 1567-68 (Fed. Cir. 1994) (reduction in fair market value of almost ninety-five percent, from $\$ 10,500$ to $\$ 500$ per acre, would clearly constitute a total taking).

34. See ZIEGLER, RATHKOPF's, supra note 2, § 6:15; see generally LAITOS, supra note 9.

35. See discussion infra Part II.A; see discussion supra Part II.C.

36. ZIEGLER, RATHKOPF's, supra note $2, \S 6: 30$.

37. Id.

38. The U.S. Supreme Court's decision in Lucas v. South Carolina Coastal Council, 505 U.S. 1003 (1992) clarifies that a categorical taking occurs not only when an owner is denied all beneficial use of the land but also when the uses allowed deny an owner all economically viable use of the land.

39. See, e.g., Helms v. City of Charlotte, 122 S.E.2d 817 (N.C. 1961); see also Palazzolo v. Rhode Island, 533 U.S. 606 (2001) (owner retained an economically viable use of his land where regulation allowed a residence to be built on the land, which had a market value of $\$ 200,000$ - a decrease in market value of about ninety-four percent from the market value of $\$ 3,150,000$ if fully developed); Walcek v. United States, 303 F.3d 1349 (Fed. Cir. 2002) (applying whole parcel analysis to wetland regulation taking claim and ruling that adjustment of base value of owner's land for inflation or deflation was not warranted to determine extent of economic impact of regulation); Am. Nat'l Bank \& Trust Co. of Chi. v. Vill. of Winfield, 274 N.E.2d 144 (Ill. App. Ct. 1971); McConnell v. Inc. Vill. of Tuckahoe, 25 A.D.2d 441 (N.Y. App. Div. 1966); Cf. Munoz Realty Corp. v. Borough of Verona, 225 A.2d 594 (N.J. Super. Ct. App. Div. 1966) (evidence failed to show that homes could not be built without cellars and sold at a fair profit or that lots could not be sold unimproved for a fair price to seller), aff'd, 225 A.2d 569 (N.J. 1966). 
there was no market value or demand for commercial use of the land. ${ }^{40}$

Government interventions that regulate housing are generally permissible if they leave the owner with an economically viable use of the land. $^{41}$ This general rule is true for most ordinary government planning restrictions on building development, such as construction standards related to building bulk and height, lot size, setbacks, open space, fences, building design, landscaping, and parking. ${ }^{42}$ Similarly, regarding rent control, the U.S. Supreme Court has upheld the general constitutionality of rent restrictions in several court cases dating back to World War II. ${ }^{43}$ In those cases, the Court focused on the increased war-time power of the government and discussed the takings issue and property rights related to housing. The Court ruled that setting maximum rent prices did not constitute a taking unless the restrictions went so far as to be confiscatory. ${ }^{44}$ The Court noted that although rent control "may reduce the value of the property regulated," it was not unconstitutional. ${ }^{45}$

Today, government rent control regulation would likely be considered a taking for which compensation must be paid only if the regulation, as applied to an owner's property, did not provide the private owner with an "economically viable return" on the land and buildings as an operational investment. $^{46}$ More broadly, a confiscation claim to a government restriction respecting rent control, tenant eviction protection, or apartmentto-ownership conversion could be successfully asserted where the regulation, as applied, merely denies an owner a fair and reasonable return

40. See People ex rel. St. Albans-Springfield Corp. v. Connell, 177 N.E. 313 (N.Y. 1931); see also Opgal, Inc. v. Burns, 189 N.Y.S.2d 606 (N.Y. Sup. Ct. 1959) (because there were approximately 1,300 acres of industrially zoned land in use in the town, 800 acres of undeveloped industrially zoned land, and approximately 5,800 acres of vacant land zoned for industrial use in the county and the neighboring county at the time the plaintiff's land was zoned from residential to industrial, there was no present need for further industrial rezoning; rezoning plaintiff's land was restrictive and unconstitutional), aff'd, 10 A.D.2d 977 (N.Y. App. Div. 1960), aff'd, 173 N.E.2d 50 (N.Y. 1961).

41. ZIEGLER, RATHKOPF's, supra note $2, \S \S 6: 22,6: 51$.

42. See Pennell v. City of San Jose, 485 U.S. 1, 20 (1988) (Scalia, J., dissenting) ("Traditional land-use regulation (short of that which totally destroys the economic value of property) does not violate [fairness principles] .... Thus, the common zoning regulations requiring subdivisions to observe lot-size and set-back restrictions, and to dedicate certain areas to public streets, are in accord with our constitutional traditions because the proposed property use would otherwise be the cause of excessive congestion.").

43. See, e.g., Woods v. Cloyd W. Miller Co., 333 U.S. 138 (1948); Bowles v. Willingham, 321 U.S. 503 (1944).

44. Bowles, 321 U.S. at 516-17.

45. Id. at 517.

46. See, e.g., Adamson Cos. v. City of Malibu, 854 F. Supp. 1476, 1502 (C.D. Cal. 1994) (rent control ordinance); Aspen-Tarpon Springs Ltd. P'ship v. Stuart, 635 So. 2d 61 (Fla. Dist. Ct. App. 1994) (conditions on change of use of mobile home park); Manocherian v. Lenox Hill Hosp., 643 N.E.2d 479 (N.Y. 1994) (requirement on landlord relating to renewal leases). 
on his investment. ${ }^{47}$ Court decisions have utilized different takings analyses in evaluating whether various types of rent control and tenant protection provisions are confiscatory. ${ }^{48}$ Typically, the key question in these cases is what constitutes a fair return on investment. ${ }^{49}$ While a variety of fair return formulas may be permissible, ${ }^{50}$ including a net operating income ratio formula, ${ }^{51}$ courts have ruled that landlords are not constitutionally entitled to market value rates of return on their investment. $^{52}$

In determining a fair return, some courts have held that inflation must be taken into account, ${ }^{53}$ and every dollar for capital improvement the landlord puts into the property constitutes an investment for which a fair and reasonable return must be allowed. ${ }^{54}$ In Richardson v. City \& County of Honolulu, ${ }^{55}$ a federal District Court held a local rent control ordinance confiscatory based on a straightforward fair return formula. ${ }^{56}$ The Court ruled that by indiscriminately basing maximum rent allowed on the initial rent paid under a lease and by neglecting to provide a mechanism for

47. See W. Dennis Keating, Rent Control: Fair Return, Landlord Hardship, and Regulatory takings, 12 ZONING \& PLAN. L. REP. 169 (1989); see also Santa Monica Beach, Ltd. V. Superior Court, 968 P.2d 993, 1002 (Cal. 1999) (rejecting a substantive due process claim to rent control law; " $[\mathrm{C}]$ ourts have employed the fair return analysis to price regulation cases whether the contested regulation is dominated as a taking or a deprivation of property without due process.").

48. See generally Karl Manheim, Tenant Eviction Protection and the Takings Clause, 1989 WIS. L. REV. 925.

49. See Kenneth K. Baar, Guidelines for Drafting Rent Control Laws: Lessons of a Decade, 35 RUTGERS L. REV. 721, 784-816 (1983). The U.S. Supreme Court has generally defined fair return in this context as a "return ... commensurate with returns on investments in other enterprises having corresponding risks. That return, moreover, should be sufficient

$l$ to . . extract capitol." Fed. Power Comm'n v. Hope Natural Gas Co., 320 U.S. 591, 603 (1944). See also In re Permian Basin Area Rate Cases, 390 U.S. 747, 792 (1968) ("The court must determine whether the [regulation] may reasonably be expected to maintain financial integrity, attract necessary capitol, and fairly compensate investors for the risks they have assumed, and yet provide appropriate protection for the relevant public interests, both existing and foreseeable.").

50. See Kavanau v. Santa Monica Rent Control Bd., 941 P.2d 851, 858-59 (Cal. 1997) (summarizing a number of important criteria for evaluating whether regulation as applied provides a "fair return" on investment).

51. Parks v. Rent Control Bd., 526 A.2d 685, 686 (N.J. 1987).

52. See generally San Marcos Mobilehome Park Owners Ass'n v. City of San Marcos, 238 Cal. Rptr. 290 (Cal. Ct. App. 1987); Parks, 526 A.2d 685.

53. Assistance, Inc. v. Teledyne Indus., Inc., 112 Cal. Rptr. 418 (Cal. Ct. App. 1974).

54. Sierra Lake Reserve v. City of Rocklin, 938 F.2d 951, 958 (9th Cir. 1991), vacated, 506 U.S. 802 (1992); see also Main Union Assocs. v. Twp. of Little Falls Rent Leveling Bd., 703 A.2d 971 (N.J. Super. Ct. App. Div. 1997) (absence of provision for capital improvement surcharge did not render rent control ordinance unconstitutional on its face since the ordinance allowed rent increases to provide a just and reasonable return).

55. Richardson v. City \& Cnty of Honolulu, 759 F. Supp. 1477 (D. Haw. 1991).

56. Id. 
adjustment or review, the law operated to deprive owners of a just and reasonable rate of return. ${ }^{57}$ The Court held that tying rent increases to general increases in prices and incomes would not result in a fair return on investment because there was substantial evidence that the base rate of initial rent paid, which served as a basis for this calculation, would often be far below fair market rental value. ${ }^{58}$

The New York Court of Appeals applied a similar economically viable use analysis in Seawall Associates v. City of New York. ${ }^{59}$ The Court held a local ordinance enacted to preserve and maintain low rent singleroom occupancy (SRO) housing within the City of New York confiscatory. ${ }^{60}$ The law, among other requirements, prohibited property owners from altering, demolishing, or converting their buildings to any other use; compelled owners to restore any uninhabitable unit to habitable condition; and required owners to keep all their units occupied as SRO housing. ${ }^{61}$ The court analyzed the impact of the law on property owners' basic rights "to possess, use, and dispose" of their buildings and found that the law substantially impaired each of these rights. ${ }^{62}$ The court further noted that the mandatory rental provisions, together with the above requirements, denied owners of SRO buildings any right to use their properties and deprived them of an economically viable use of their properties. ${ }^{63}$ The court found that the ordinance operatively ignored the legitimate investment-backed expectations of SRO property owners and failed to establish a formula to provide owners a fair return on their investment. $^{64}$

\section{Partial Benefit-Extraction Taking Analysis}

As the U.S. Supreme Court has often stated, the Fifth Amendment's just compensation provision is "designed to bar Government from forcing some people alone to bear public burdens which, in all fairness and justice, should be borne by the public as a whole. ${ }^{165}$ As reflected in recent U.S.

57. Id. at 1489 .

58. Id. at $1489-90$.

59. Seawall Assocs. v. City of New York, 542 N.E.2d 1059 (N.Y. 1989).

60. $I d$.

61. Id. at $1060-61$.

62. Id. at 1065-68.

63. Seawall Assocs., 542 N.E.2d at 1069.

64. Id; see also Aspen-Tarpon Springs Ltd. P'ship v. Stuart, 635 So. $2 d 61$ (Fla. Dist. Ct. App. 1994) (statute requiring owner, if changing use of mobile home park, to either buy tenants' homes or pay to have homes moved held unconstitutional since not economically feasible).

65. See, e.g., Dolan v. City of Tigard, 512 U.S. 374 (1994); Concrete Pipe \& Prods. of Cal., Inc. v. Constr. Laborers Pension Trust for S. Cal., 508 U.S. 602 (1993); Nollan v. Cal. Coastal Comm'n, 483 U.S. 825 (1987); Penn Cent. Transp. Co. v. City of New York, 438 U.S. 104 (1978). 
Supreme Court decisions, the partial taking analysis explicitly recognizes that a regulation may affect an unconstitutional taking of private property without amounting to a categorical or per se taking, either by denying an owner all economically viable use or by resulting in the physical occupation of the owner's land. ${ }^{66}$

Under the benefit-extraction taking analysis, confiscation occurs when the burden imposed on a private owner, in view of the nature of the government action involved, is one that the public fairly and justly should pay for as a whole through taxing and spending. ${ }^{67}$ Justice and fairness require that economic injuries caused by regulation be compensated by the government rather than remain disproportionately concentrated on regulated and burdened private owners. ${ }^{68}$ Courts in these cases find that the regulation in question is designed primarily to secure the acquisition of public resources and extract from the affected owners a public benefit that is not substantially attributable to some problem related to the owners' conduct. $^{69}$ This takings analysis is reflected in a very long line of state court decisions and in a number of recent U.S. Supreme Court decisions dealing with "development exactions."

66. See ZIEGLER, RATHKOPF's, supra note 2 , § 6:51; see also Dolan, 512 U.S. at 374; Nollan, 483 U.S. at 825.

67. ZIEGLER, RATHKOPF's, supra note 2, $\S \S 6: 51-52$.

68. See ZIEGLER, RATHKOPF's, supra note $2, \S 6: 51$; see also Fla. Rock Indus., Inc. v. United States, 18 F.3d 1560, 1571 (Fed. Cir. 1994); see generally Fundamental Fairness, supra note 10.

69. See, e.g., E. Enters. v. Apfel, 524 U.S. 498, 528-29, 537 (1998) (the Takings Clause requires fair assessment of burdens imposed related to causation and proportionality); Lucas v. S.C. Coastal Council, 505 U.S. 1003, 1018-26 (1992) (while regulation often may be interpreted as either "harm-preventing" or "benefit-conferring," there must be heightened judicial review of the nexus between the conduct restricted and the social problem addressed by regulation in situations where there is a "heightened risk that private property is being pressed into some form of public service"); United States v. Armstrong, 364 U.S. 40, 49 (1960) (the Takings Clause "was designed to bar Government from forcing some people alone to bear public burdens which, in all fairness and justice, should be borne by the public as a whole."); Pa. Coal Co. v. Mahon, 260 U.S. 393, 416 (1922) ("[A] strong public desire to improve the public condition is not enough to warrant achieving the desire by a shorter cut than the constitutional way of paying for the change ... . [T] he question at bottom is upon whom the loss of the [regulatory] changes desired should fall."); Monongahela Navigation Co. v. United States, 148 U.S. 312, 325 (1893) (the Takings Clause "prevents the public from loading upon one individual more than his just share of the burdens of government, and says that when he surrenders to the public something more and different from that which is exacted from other members of the public, a full and just equivalent shall be returned to him.").

70. Dolan, 512 U.S. 374 (holding that there must be rough proportionality between amount of development exaction and extent of specific problem related to or need generated by particular development proposal); Nollan, 483 U.S. 825 (holding that there must be a substantial relationship between nature of development exaction and some specific problem related to or need generated by particular development proposal); see also Fundamental Fairness, supra note 10, at 11-23. 
principle at work here is that development exactions must be reasonably related in nature to some problem caused by development and reasonably related in amount to the magnitude of that problem.

For example, a regulatory condition imposed on the development of food markets mandating that they give free food to persons with an official "low income" card would be a taking requiring compensation. The stores would simply be convenient targets of a regulation providing free food to persons with a low income, though the stores were not a significant cause of the poverty that the regulation addresses. Under this analysis, the public benefit secured by such a regulation - feeding the poor - is considered constitutionally appropriate, but that burden must be publicly shared through taxing and spending powers. ${ }^{72}$ This benefit-extraction taking analysis would also apply to regulations imposed on private owners to house the poor or shelter the homeless. ${ }^{73}$

This taking analysis has been applied in cases involving impact fees for public housing and other similar regulatory schemes. ${ }^{74}$ For example,

71. Dolan, 512 U.S. 374 (holding that there must be rough proportionality between amount of development exaction and extent of specific problem related to or need generated by particular development proposal); Nollan, 483 U.S. 825 (holding there must be a substantial relationship between nature of development exaction and some specific problem related to or need generated by particular development proposal); see also ZIEGLER, RATHKOPF'S , supra note 2, $\S 6: 10 ;$ Fundamental Fairness, supra note 10, at 11-23; see generally LAITOS, supra note 9.

72. This type of partial taking analysis is reflected, in another context, in California Chief Justice Rose Bird's dissenting opinion in Yarborough v. Superior Court, 702 P.2d 583, 432 (Cal. 1985) (quoting Yarbrough v. Superior Court, 197 Cal.Rptr. 737, 744-45 (Cal. Ct. App. 1983) (King, J., concurring):

No one would dare suggest courts have the authority to order a doctor, dentist or any other professional to provide free services, while at the same time telling them they must personally pay their own overhead charges for that time. No crystal ball is necessary to foresee the public outrage which would erupt if we ordered grocery store owners to give indigents two months of free groceries or automobile dealers to give them two months of free cars. Lawyers in our society are entitled to no greater privileges than the butcher, the baker and the candlestick maker; but they certainly are entitled to no less.

73. But cf. Commercial Builders of N. Cal. v. City of Sacramento, 941 F.2d 872, 873 (9th Cir. 1991) (upholding low-income housing fee on commercial building permits); Holmdel Builders Ass'n v. Twp. of Holmdel, 583 A.2d 277, 295 (N.J. 1990) (upholding low-income housing fee on commercial building permits); Seawall Assocs. v. City of New York, 542 N.E.2d 1059, 1069 (N.Y. 1989) (affirming buyout and other burdens imposed on single-room only housing to address problems of homeless).

74. See, e.g., Commercial Builders of N. California v. City of Sacramento, 941 F.2d 872 (9th Cir. 1991) (upholding city ordinance that conditioned nonresidential building permits on payment of fee to offset burdens associated with influx of low-income workers to work on such developments); S. Shell Inv. v. Town of Wrightsville Beach, 703 F. Supp. 1192, 1206 (E.D.N.C. 1988) (rejecting a claim that a three-fold increase in utility system and tap water impact fees was arbitrary even though the fees bore no relationship to the stated purposes and were intermixed with government funds), aff'd, 900 F.2d 255 (4th Cir. 1990); Bldg. 
the California Court of Appeals recently ruled in favor of the housing developer when it struck down an affordable housing impact fee imposed on a new housing development. ${ }^{75}$ The court held that the increase in the affordable housing fee was not "reasonably justified" under existing law because there was no reasonable relationship between the amount of increase in the fee and some demonstrated "deleterious public impact of development." 76 The court relied on the lack of evidence of any relationship between the extent of the city's affordable housing need and the development of housing units by the developer. ${ }^{77}$ Other decisions have held regulatory conditions on housing confiscatory under benefit-extraction taking analysis. ${ }^{78}$ It has also been applied to public rent control schemes where the burden is arbitrarily placed on a disfavored group of tenants. ${ }^{79}$

\section{The HUTTEN-CZAPSKA CASE: Property, HuMAN RightS, AND CONFISCATION ClaimS}

In 2006, the European Court of Human Rights (ECHR) heard a housing case involving the government's imposition of long-term rent controls on private owners of housing in Poland. ${ }^{80}$ The suit originated in the Polish courts by Maria Hutten-Czapska, a French national with property in Poland. Restrictive landlord provisions had been passed in response to the housing shortage in Poland - the most severe shortage in Eastern Europe after World War II. ${ }^{81}$ The laws imposed a number of rent

Indus. Ass'n of Cent. Cal. v. City of Patterson, 90 Cal. Rptr.3d 63 (Cal. Ct. App.), cert. denied, 130 S.Ct. 660 (2009).

75. Bldg. Indus. Ass' $n, 90$ Cal.Rptr.3d at 73-74.

76. Id.

77. Id. at 74 .

78. See, e.g., Garneau v. City of Seattle, 897 F. Supp. 1318 (W.D. Wash. 1995) (exaction of cash relocation assistance for low-income tenants); Gagne v. City of Hartford, 10 Conn. L. Rptr. 630 (Conn. Super. Ct. 1994) (requiring replacement of, or "in lieu" fees for, low income housing); Aspen-Tarpon Springs Ltd. P'ship v. Stuart, 635 So. 2d 61 (Fla. Dist. Ct. App. 1994) (requirement that mobile home park owners buy tenants' homes or pay relocation costs); Prop. Owners Ass'n v. Twp. of N. Bergen, 378 A.2d 25 (N.J. 1977) (ordinance requiring landlords and other tenants to subsidize senior citizens' rents); Manocherian v. Lenox Hill Hosp., 643 N.E.2d 479 (N.Y. 1994) (requirement that owners provide renewal leases to non-private hospitals based on primary residency status of hospital's employee-subtenant); Seawall Assocs., 542 N.E.2d at 1069 (buyout and other burdens imposed on single-room-only housing to address homelessness problem); Guimont v. Clarke, 854 P.2d 1 (Wash 1993) (relocation assistance for low-income tenants); Robinson v. City of Seattle, 830 P.2d 318 (Wash. 1992) (fees required for destruction of low-income housing).

79. Prop. Owners Ass'n, $378 \mathrm{~A} .2 \mathrm{~d}$ at 33 ("[T] he initial burden falls exclusively upon the shoulders of the non-Senior Tenants, who in a given case may be financially less capable of bearing the increase than the Senior Tenants.").

80. Hutten-Czapska v. Poland, 45 Eur. Ct. H.R. 4 (2007).

81. Maureen Markham, Poland: Housing Challenge In a Time of Transition (2003) 
restrictions on landlords, including a low ceiling on rent levels such that landlords could not recover maintenance costs, much less make a profit and a return on investment. ${ }^{82}$ In 2001, the Polish Constitutional Court (PCC) held the laws unconstitutional for placing a disproportionate and excessive burden on landlords. $^{83}$ In February 2005, the PCC again found the legislation unconstitutional because it made it impossible for landlords to receive rent reasonably commensurate with the costs of property maintenance. ${ }^{84}$ The PCC directed Poland to find a way to provide HuttenCzapska and the other 100,000 similarly situated landlords a reasonable level of rent or to provide them with a way to mitigate the consequences of the state-controlled rent increases. 85

The Polish government requested referral of the case to the Grand Chamber of the ECHR. The Grand Chamber relied on the European Convention on Human Rights ${ }^{86}$ and the Charter of Fundamental Rights of the European Union, which states that the right to property is a fundamental right. ${ }^{87}$ The Grand Chamber agreed that Poland, which inherited an abominable housing situation from the communist regime, was in the difficult position of balancing conflicting interests of landlords and tenants. ${ }^{88}$ However, the Polish government failed to distribute the social and financial burden fairly. The ECHR essentially applied the benefitextraction confiscation analysis, as used by U.S. courts, and found that Poland had placed the burden on one particular social group. ${ }^{89}$ By failing to establish a "reasonable relation of proportionality" between the legitimate goal of the Polish government and the restrictions utilized to achieve that goal, the ECHR ruled that the government violated Article 1 of Protocol No. 1 of the Convention. 90

Had this case arisen in the United States, the outcome would have likely been the same. Under both the economically viable use and the

(unpublished HUT-236M paper, Harvard University), http://www.jchs.harvard.edu/ education/oustanding_student_papers/markham_poland_03.pdf.

82. Hutten-Czapska, 45 Eur. Ct. H.R. at 9237.

83. Id.

84. Id. at 9 ff 136-41.

85. Hutten-Czapska, 45 Eur. Ct. H.R. at $ๆ 237$.

86. Protocol to the Convention for the Protection of Human Rights and Fundamental Freedoms of 20 March 1952, as amended by Protocol No. 11, May 11, 1994, ETS No. 155 (entered into force Nov. 1, 1998), available at http://www.ena.lu/protocol_convention_ protection_human_rights_fundamental_freedoms_paris_march_1952_amended_version-213069.

87. Charter of Fundamental Rights of the European Union, art. 17, I 1, 2000 O.J. (C 364) $1,12$.

88. Hutten-Czapska, 45 Eur. Ct. H.R. at ๆ 225.

89. Id.

90. Id. at 167; see also Spadea \& Scalabrino v. Italy, 21 Eur. Ct. H.R. 482 (1996) (discussing the impossibility for a landlord to obtain the enforcement of a decision evicting a tenant). 
benefit-extraction analyses utilized in U.S. court decisions, the long-term rent controls in Hutten-Czapska would have been held an unconstitutional taking of the landlord's property. ${ }^{91}$ Future ECHR decisions may continue to reflect, at least in part, the analysis utilized in U.S. court decisions interpreting the taking of private property rights by government regulatory interventions. The three lines of constitutional regulatory takings analysis utilized by U.S. courts may be consulted for possible lines of argument and analysis in future property rights cases arising under the Charter of Fundamental Rights of the European Union and the European Convention on Human Rights. ${ }^{92}$

\section{OWNERSHIP OF PRIVATE PROPERTY, OVERREGULATION, AND JUDICIAL RESTRAINTS}

The Hutten-Czapscka decision is a classic example of how a wellmeaning housing rule can create negative consequences such that private entrepreneurial choices become frustrated and defeated. In Poland, longterm rent controls designed to address an acute housing shortage made it impossible for owners of rental housing to enjoy any economic gains or viable ownership benefits. The only solution was first a judicial override of the rent control law by the Polish courts then by the ECHR Grand Chamber. The United States has also experienced this sequence of good-faith government interference with private property markets resulting in economic marketplace chaos requiring judicial intervention to restore fairness and economic growth. ${ }^{93}$ Such a pattern is not uncommon when a government decides to assert its authority over decisions involving rights to privately owned property.

Conversely, several positive market consequences result when private parties contract for the use and development of property free from unreasonable government interference. Property ownership permits private economic ordering and helps secure the investment capital necessary for financial growth. Moreover, property provides a benefit to non-owners, who are better off because an owner decided to develop, transfer, or make active use of the property. When the private exercise of a property right benefits third parties, like parties other than the owner or a party to whom the property is conveyed, the property is generating a positive externality.

91. See supra notes $65-71$ and accompanying text.

92. See Charter of Fundamental Rights of the European Union, art. 17, I 1, 2000 O.J. (C 364) 1, 12; Protocol to the Convention for the Protection of Human Rights and Fundamental Freedoms of 20 March 1952, as amended by Protocol No. 11, May 11, 1994, ETS No. 155 (entered into force Nov. 1, 1998), available at http://www.ena.lu/protocol_convention_ protection_human_rights_fundamental_freedoms_paris_march_1952_amended_version-213069.

93. See discussion supra Part II. 
When the private property is actively used and not passively held, it becomes a "public good." A4 A public good is an economist's term for a resource whose use by a private party benefits not only the owner but also third parties. 95

Private property, when transformed by the owner into a valuable commodity, becomes a public good because the owner's behavior has a positive effect on parties that are external to both the owner and the party to whom the property is transferred. For example, property development for residential purposes has repercussions beyond the owner when the use makes the property economically productive. For instance, if an owner subdivides land and builds homes, second parties directly benefit from this use. These include workers employed during the construction of the homes, agents who sell the homes, and future homeowners. Third parties benefit indirectly, like government agencies whose property tax base is expanded. Employers of those who live in the new homes benefit because otherwise they might have had to provide housing for their employees. Also, the overall local economy benefits from the purchasing power of new consumers now living in the area.

Despite unregulated private property creating a public good, especially when that property becomes housing, the government may choose to regulate the uses of that property and restrict the choices of the owners. Controls over land use, housing, and property have been common in Western civilization ever since the Roman Empire introduced regulations for setback lines for buildings and trees in as early as 450 B.C. ${ }^{96}$ In the United States, although land use regulations existed since the colonial era, it wasn't until the twentieth century that the demand for regulations of real estate development became significant. ${ }^{97}$ First, as the United States moved toward a more urban society, "city governments sought to gain control over the location of industry, commerce, and housing" through zoning. ${ }^{98} \mathrm{New}$ York City, for example, adopted its first comprehensive zoning ordinance in $1916 .{ }^{99}$ By the $1930 \mathrm{~s}$, most urban areas had adopted some kind of zoning law. ${ }^{100}$ After World War II, increasing suburbanization in the United States led to municipal regulations, controlling the size and type of such housing developments. ${ }^{101}$ Beginning in the $1970 \mathrm{~s}$, once again growing urban population necessitated regional planning and even more

94. See Thomas W. Merrill, Dolan v. City of Tigard: Constitutional Rights as Public Goods, 72 DENV. U. L. REV. 859 (1995).

95. See generally id.

96. 6 West's Encyclopedia of American Law 185 (Jeffrey Lehman \& Shirelle Phelps eds., 2nd ed. 2005).

97. Id.

98. Id.

99. Id.

100. Id.

101. Id. 
restrictive housing and property policies. ${ }^{102}$

One such restrictive policy is exclusionary zoning. "Exclusionary zoning is using zoning to further the parochial interests of a particular municipality, at the expense of surrounding regions." 103 It takes various forms, such as setting a minimum lot or house size or prohibiting multifamily housing or mobile homes. ${ }^{104}$ This type of zoning "fences out" low-income housing and decreases the overall supply of housing. ${ }^{105}$ Exclusionary zoning thus advances economic, social, and often racial segregation. ${ }^{106}$ It takes advantage of regional development to create and maintain homogenous communities and building affluent municipalities. ${ }^{107}$ The practice certainly goes against the idea that municipal zoning aims to advance general welfare.

Such government interference with private housing decisions produces several negative consequences. ${ }^{108}$ Generally, excessive regulation smothers the creativity of marketplace actors whose decisions fuel economic growth. $^{109}$ Additionally, regulation fails to enhance personal liberty since the government's exercise of police power inhibits it. ${ }^{110}$ Government regulation limits a person's ability to make fundamental choices about how best to deploy resources productively, and it entails high

102. Id.

103. West's Encyclopedia of American Law, supra note 96, at 187.

104. Id.

105. Id.

106. Id.

107. Id.

108. One such intervention is rent control, where government artificially restricts rent increases or limits the landlord's ability to charge a service fee to tenants and thus interferes with the market supply, demand and price, rendering the market's self-corrective features inoperative. See, e.g., Guggenheim v. City of Goleta, 2010 WL 5174984 (9th Cir. December 22,2010 ) (en banc) (holding that a mobile home park rent control ordinance constituted a regulatory taking. The ordinance was a wealth transfer mechanism, which placed a high burden on private owners to accomplish city goals that could have been accomplished by other means and went "too far." The 9th Circuit, sitting en banc, reversed, holding that the ordinance furthered legitimate government purpose, as required by due process, and thus did not constitute taking).

Different tax rates among localities, concentrating higher tax rates in the centrally located urban developments encourage suburbanization and aggravate the troubles of central-city business properties. Through various policies, such as tax incentives, low interest loans, easy credit, secondary mortgage market and capital gains protection, the government creates over-stimulation of demand. These policies led to the near collapse of the American housing market in 2008-2009.

109. See generally StePHen G. BREYeR, Regulation AND ITS REForm (1982); Philip K. Howard, The Death of Common Sense: How Law is Suffocating America (1994); Susan Rose-Ackerman, RethinkIng the Progressive agenda: The Reform of the AMERICAN REGULATORY STATE (1992).

110. See Rose-ACKERMAN, supra note 109, at 133-34. 
administrative costs. ${ }^{111}$

Three other negative consequences that flow from unchecked regulation have a particular impact on third parties. The first occurs when the government, not properly monitored through meaningful judicial review, disproportionately burdens one or a very small number of individuals, while not subjecting similarly situated persons to equivalent burdens. $^{112}$ If this kind of regulation paralyzes the courts, third parties benefit by not having to share the cost of regulation, and they become free riders. 113

Another third party consequence is the creation of what Professor Frank Michelman calls "demoralization costs."114 These costs "accrue to [property owners] and their sympathizers specifically from the realization that [no judicial relief] is offered" when government over-regulates. ${ }^{115}$ These costs are the effect that excessive property regulation has on other property owners who witness but do not directly experience the regulatory impact. ${ }^{116}$ These third parties may be less inclined to develop their property when they see a neighbor saddled with unrelieved, burdensome regulation. Furthermore, unrestricted regulation can change the preexisting distribution of wealth by forcing or authorizing exchanges of property between property owners without compensating them for their loss. ${ }^{117}$ Such forced exchanges occur with rent-control laws that burden landlords and benefit tenants ${ }^{\mathrm{R}}$ and with certain environmental laws that deprive property owners of environmentally sensitive land for the benefit of the public.

Another harm resulting from government interference with private property autonomy is that the disadvantaged often bear the brunt of any attendant harm. ${ }^{120}$ Typically, when regulation creates costs or conditions of

111. Norman Kailin, Substantive Due Process: A Doctrine for Regulatory Control, 13 Sw. U. L. REV. 479, 480 (1983).

112. See LaITos, supra note $9, \S 1.04(\mathrm{C})(1)$.

113. See Dolan v. City of Tigard, 512 U.S. 374, 385-86 (1994); Armstrong v. United States, 364 U.S. 40, 49 (1960); see also LaIros, supra note 9, § 1.04(C)(1).

114. Frank I. Michelman, Property, Utility, and Fairness: Comments on the Ethical Foundations of "Just Compensation" Law, 80 HARV. L. REV. 1165, 1214 (1967) [hereinafter Michelman, Property].

115. Id.

116. LAITOS, supra note $9, \S 1.04(\mathrm{C})(1)$.

117. EPSTEIN, supra note 24 , at $95-200$.

118. Pennell v. City of San Jose, 485 U.S. 1, 19-23 (1988) (Scalia, J., concurring in part and dissenting in part).

119. Dolan, 512 U.S. at $386-87,391-93$ (1994).

120. See Philip P. Houle, Eminent Domain, Police Power and Business Regulation: Economic Liberty and the Constitution, 92 W. Va. L. Rev. 51, 61 (1989); Anthony S. McCaskey, Comment, Thesis and Antithesis of Liberty of Contract: Excess in Lochner and Johnson Controls, 3 SETON HALl Const. L.J. 409, 459 (1993); James L. Oakes, "Property Rights" in Constitutional Analysis Today, 56 WASH. L. REv. 583, 624 (1981); Note, 
scarcity, the poor suffer the most. ${ }^{121}$ These distributional consequences are worsened because the poor are the least able to alter legislative decisions that produce over-regulation. ${ }^{122}$ Moreover, legislators enacting police power regulation are often influenced by interest-group politics. The economically disadvantaged have neither the funds nor the expertise to access lobbyists who have the most influence over legislators. Therefore, the interests of the disadvantaged are not frequently reflected in police power legislation. ${ }^{123}$

For private property to have the potential to maximize the welfare of not only owners and those with whom they engage in transactions regarding the property but also third parties who benefit from property's public goods component, courts should protect property uses from over-zealous exercises of the police power. Courts could then preserve external benefits for third parties that result from reducing regulation of private property. The judiciary can protect both individual choices and the public good of property use by applying the legal doctrines established in constitutions that allow courts to halt excessive regulations. In the United States, the U.S. Constitution's Takings Clause provides this protection. ${ }^{124}$

\section{SOCIAL AND POLICY BENEFITS OF THE TAKINGS ClAUSE}

The Takings Clause of the U.S. Constitution is a limit on the ability of government actions to take or otherwise unreasonably burden private rights

Resurrecting Economic Rights: The Doctrine of Due Process Reconsidered, 103 HARV. L. REV. 1363, 1371 (1990).

121. LAITOS, supra note $9, \S 1.04(\mathrm{C})(1)$.

122. Houle, supra note 120 , at 59,98 .

123. See Mancur M. Olson, The Logic of Collective Action: Public Goods and THEORY OF GROUPS 165-67 (2d ed. 1971); see also Glynn S. Lunney, Jr., A Critical Reexamination of the Takings Jurisprudence, 90 MICH. L. REV. 1892, 1950-51 (1992) (concentrated groups are likely to have disproportionately greater resources available than a dispersed group of poor individuals and are more likely to use the available resources more effectively to influence the legislature).

124. Legal Scholars have increasingly argued that property rights should be accorded constitutional protection equal to those enjoyed by other individual rights. See, e.g.,

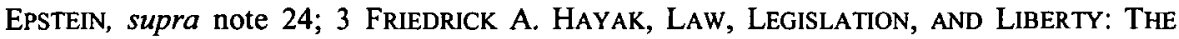
Political Order of a Free PeOPle (1979); Rose-ACKerman, supra note 109; BERNARd H.

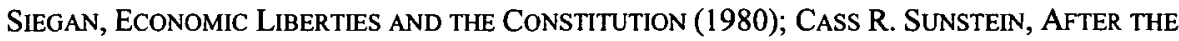
Rights Revolution: Reconceiving the Regulatory State (1990); Ronald J. Krotoszynski, Jr., Fundamental Property Rights, 85 GEO. L.J. 555 (1997); Douglas W. Kmiec, Property and Economic Liberty as Civil Rights: The Magisterial History of James W. Ely, Jr., 52 VAND. L. Rev. 737 (1999) (reviewing PROPERTY RIGHTS IN AMERICAN HISTORY (James W. Ely, Jr. ed. 1997)). But see C. Edwin Baker, Property and its Relation to Constitutionally Protected Liberty, 134 U. PA. L. REv. 741 (1986); Alan E. Brownstein, Constitutional Wish Granting and the Property Rights Genie, 13 CONST. COMMENT. 7 (1996). 
in land, property, or housing. ${ }^{125}$ It serves an important check on government decisions that interfere with private choices about property interests. There are many social and policy benefits that follow from this kind of constitutional limit on governmental meddling in the economic market.

A. The Takings Clause prevents government from denying owners any use of their property

When the government denies all economically beneficial or productive use of property, it affects a per se taking. ${ }^{126}$ Some courts have even decided that a per se taking can occur when the government substantially deprives a property owner of the use and enjoyment of property. $^{127}$ A compensable temporary taking occurs when an owner is prevented from doing anything with his or her property for a limited period of time. $^{128}$ In Lucas $v$. South Carolina Coastal Council, the Supreme Court clarified why the Takings Clause is proper by invoking Lockean-liberal assumptions about private property: "[O]ur prior takings cases evince an abiding concern for the productive use of, and economic investment in, land."

\section{B. The Takings Clause promotes economic prosperity}

One of the assumptions behind the Takings Clause is that if private property rights are secure, ownership in real property is protected. The free market is allowed to operate without extensive government interference, and individuals in these communities are economically better off. Prosperity follows. The Takings Clause is designed to curb aggressive government decisions that are inconsistent with these three premises.

Moreover, if legislatures are able to change private property into public property, there has been a transfer of resources from private hands to the general community. Commentators have warned that when private owners have too many of their assets and earnings redistributed by the force of law, they will become discouraged and may stop developing their

126. Lucas v. S. C. Coastal Council, 505 U.S. 1003, 1015 (1992).

127. Van Wyk v. Public Serv. Co., 996 P.2d 193 (Colo. App. 1999), rev'd in part, 27 P.3d 377 (Colo. 2001).

128. Ali v. City of Los Angeles, 91 Cal. Rptr.2d 458 (Cal. Ct. App. 1999) (two-year temporary taking).

129. Lucas, 505 U.S. at 1019 n.8; see also Shelden v. United States, 7 F.3d 1022 (Fed. Cir. 1993) (taking when government action totally destroyed value of a mortgage owned by the plaintiff). 
property. ${ }^{130}$ Property owners incur these demoralization costs when the law interferes with their expectations of keeping and controlling the properties in which they have invested. One important purpose of the Constitution's Takings Clause is to prevent this.

\section{The Takings Clause encourages efficient decision making}

The mere presence of the Takings Clause in the U.S. Constitution deters excessive or unreasonable government action because government actors are aware that private parties may challenge such action in court. For example, exclusionary zoning is a public and collective decision that stands in stark contrast to a system of private property decision-making, in which individual owners make choices about how to use their property. The Takings Clause might permit owners to make choices about efficient land use instead of a more distant and collective government choice. ${ }^{131}$

\section{The Takings Clause requires the government to act fairly}

One of the central tenets of the Takings Clause is that government should not extract a public benefit from private land and property owners. $^{132}$ Indeed, in Armstrong $v$. United States, ${ }^{133}$ a seminal case in 1960, the Supreme Court explained that the principal purpose of the Takings Clause was "to bar Government from forcing some people alone to bear public burdens which, in all fairness and justice, should be borne by the public as a whole." 134 Other courts have since decided that the essence of a takings claim, particularly a partial takings claim, is the extent to which a police power regulation has singled out one or a few property owners to bear burdens disproportionately, while the community shares the benefits. ${ }^{135}$ When property owners have not contributed more to a problem, then it is a taking if a regulation makes them remedy the problem. ${ }^{36}$ Even though the police power regulation may be well-intentioned, the law cannot

130. See Michelman, Property, supra note 114, at 1211-14; see also JEREMY BENTHAM, Principles of the Civil Code, in Theory of Legislation 109-14, 121 (C.K. Ogden ed. 1987).

131. EPSTEIN, supra note 24, at 265.

132. ZIEGLER, RATHKOPF's, supra note $2, \S 6: 16$.

133. Armstrong v. United States, 364 U.S. 40 (1960).

134. Id. at 44.

135. See, e.g., Christopher Lake Dev. Co. v. St. Louis Cnty., 35 F.3d 1269, 1275 (8th Cir. 1994); Creppel v. United States, 41 F.3d 627, 631 (Fed. Cir. 1994); Cardan Oil Co. v. City of Phoenix, 593 P.2d 656, 659 (Ariz. 1979); Manocherian v. Lenox Hill Hosp., 643 N.E.2d 479,484 (N.Y. 1994).

136. See, e.g., Bonnie Briar Syndicate, Inc. v. Town of Mamaroneck, 699 N.Y.S.2d 721 (N.Y. 1999) (discussing whether plaintiffs had been singled out or involuntarily conscripted to provide open space to the public). 
force some people to confer benefits on other similarly-situated property owners. $^{137}$

\section{E. The Takings Clause contributes to individual liberty}

In a free market system, each person's welfare is maximized if autonomous decision-making is allowed. When the government prevents such autonomy by making public and collective choices (such as a zoning or rent control law), the market is frustrated, and individual benefits may be frustrated. The Takings Clause unleashes individual liberty by limiting government actions that interfere with individualized choice about land, property, and ownership rights. Such liberty of choice in turn yields economic prosperity. ${ }^{138}$

\section{CONCLUSION}

Although government housing policies are often said to be designed to benefit the general welfare, sometimes those same policies can result in damaging burdens to private property owners, including prospective buyers as consumers of housing. Such burdens, in turn, not only harm these existing and prospective housing owners, but also they can produce social costs that adversely affect the public as a whole. A higher law, such as the U.S. Constitution or the European Convention on Human Rights, can sometimes utilize constitutional norms to override the government policies that create these types of negative consequences for property owners and the public. Landlords and developers are not the only beneficiaries of the application of this higher law. The market for higher quality and affordable housing is often assisted when excessive or unreasonable restrictions on private housing decisions are removed.

137. See Robert C. Ellickson, Suburban Growth Controls: An Economic and Legal Analysis, 86 YALE L.J. 420 (1977); A. Dan Tarlock, Zoning and Land Use Symposium: Regulatory Takings, 60 CHI.-KENT L. REv. 23, 31 (1984).

138. EPSTEIN, supra note 24 , at viii. 